\section{Greetings from the editor}

\author{
Josef S Smolen
}

The June issue of the Annals of the Rheumatic Diseases (ARD) that you are holding in your hands today constitutes an usual annual breaking point. While the $A R D$ volume numbers relate to a full calendar year, January-December, the June issue of each volume marks the first issue for the subscription to ARD that participants of the Annual European League Against Rheumatism (EULAR) Congress receive every year in the Congress educational package and that lasts until May of the following year. Long ago, when EULAR and the BMJ Publishing Group agreed on the venture to elect $A R D$ as 'The EULAR Journal', EULAR was faced by the fact that it did not have individual members (but rather national societies as official members) and, therefore, no individual membership fees that could include an organisation's official journal, as is the case with many other specialty societies. Therefore, EULAR decided to make ARD part of the educational package for all individually registered Congress participants. Since the EULAR Congress is attended by over 14000 participants every year, this also makes $A R D$ one of the most widely circulated journals in the field.

This year's June issue comprises a number of highlights: among many other papers, you will find two EULAR recommendations and a recommendation by an international task force ${ }^{1-3}$; all three will

Correspondence to Professor Josef S Smolen, Department of Rheumatology, Medical University of Vienna, Vienna 1090, Austria;

josef.smolen.ard@meduniwien.ac.at help improve outcomes for patients with various rheumatic diseases. You will also find a viewpoint by Maarten Boers ${ }^{4}$ on the optimal design of graphs for scientific data to demonstrating their results in an easily digestible format. ARD wishes to provide you, the readers, with the best science in the field and with publications that attempt to present the data as clearly as possible; here the aspirations of the journal will undoubtedly meet with those of the authors, since both sides wish to present data in the best way to the readers. To this end, we are now also making sure that figures in $A R D$ include the actual numeric data within graphs as I promised in my first editorial last year ${ }^{5}$; it has meanwhile become a requirement in the $A R D$ submission instructions for clinical trial (and other) data, and you will have already seen the distinct data within the figures or in supplementary material in some of the latest issues as well as this issue.

In my September 2017 editorial, I also announced three new sections: 'Views on News', 'Heroes and Pillars of Rheumatology' and 'Thinking the Unthinkable'. The 'Views on News' section has already successfully started and you will find another piece by David Pisetsky in this issue. ${ }^{6}$ The first 'hero' to be covered will be Jacques Forestier by Maxime Dougados, and Gerd Burmester has started to 'think the unthinkable'-these papers will be published very soon. We welcome proposals of topics for these three sections.

This June 2018 issue comprises many articles that passed my desk as the new Editor-in-Chief of $A R D$, but many were also handled by my predecessor Tore Kvien, who led this journal for almost a decade. This gives me a renewed opportunity to thank him deeply for his vision and dedication in bringing this journal to the forefront in the field and for teaching me (and so many others) many valuable lessons-thank you, Tore!

At the end, let me please wish you the joy and satisfaction of discovering new knowledge both at the 2018 EULAR Congress and when reading $A R D$-this issue as well as all of the upcoming ones.

Funding The author has not declared a specific grant for this research from any funding agency in the public, commercial or not-for-profit sectors.

Competing interests None declared.

Patient consent Not required.

Provenance and peer review Commissioned; internally peer reviewed.

(C) Article author(s) (or their employer(s) unless otherwise stated in the text of the article) 2018. All rights reserved. No commercial use is permitted unless otherwise expressly granted.

\section{(D) Check for updates}

To cite Smolen JS. Ann Rheum Dis 2018;77:789.

Ann Rheum Dis 2018;77:789.

doi:10.1136/annrheumdis-2018-213599

\section{REFERENCES}

1 Hatemi G, Christensen R, Bang D, et al. 2018 update of the EULAR recommendations for the management of Behçet's syndrome. Ann Rheum Dis 2018;77:808-18.

2 Geenen R, Overman CL, Christensen R, et al. EULAR recommendations for the health professional's approach to pain management in inflammatory arthritis and osteoarthritis. Ann Rheum Dis 2018;77:797-807.

3 Ravelli A, Consolaro A, Horneff G, et al. Treating juvenile idiopathic arthritis to target: recommendations of an international task force. Ann Rheum Dis 2018;77:819-28.

4 Boers M. Designing effective graphs to get your message across. Ann Rheum Dis 2018;77:833-9.

5 Smolen JS. The new editor greets you. Ann Rheum Dis 2017;76:1636.

6 Pisetsky DS. How the gut inflames the joints. Ann Rheum Dis 2018;77:634-5. 